\title{
Assessment of Fecal Viral Shedding Among Children Who Have COVID-19 by Polymerase Chain Reaction
}

\section{COViD-19 Tanılı Çocuklarda Polimeraz Zincir Reaksiyonu ile Fekal Viral Yayılımın Değerlendirilmesi}

\author{
Duygu ISKENDER MAZMAN', Selim DERECl' ${ }^{1}$, Bedia DINC², Aslınur OZKAYA PARLAKAY', \\ Bekir YALCIN ${ }^{4}$, Fisun KIRCA², Burcu BERBEROGLU ATES ${ }^{1}$, Arzu Meltem DEMIR ${ }^{1}$, Gulin HIZAL'1
} Aysel UNLUSOY AKSU' ${ }^{1}$, Samil HIZLI' ${ }^{1}$

${ }^{1}$ Ankara City Hospital, Pediatric Gastroenterology Department, Ankara, Turkey

${ }^{2}$ Ankara City Hospital, Clinical Microbiology Department, Ankara, Turkey

${ }^{3}$ Ankara City Hospital, Pediatric Infectious Department, Ankara, Turkey

${ }^{4}$ Ankara City Hospital, General Pediatrics, Ankara, Turkey

\begin{abstract}
Objective: This study aimed to assess fecal viral shedding in children who have been confirmed COVID-19 by real time polymerase chain reaction (RT-PCR).

Material and Methods: We enrolled fifty inpatient children who have been confirmed COVID-19 during first wave of outbreak in our region. All of the patients have been twice confirmed by RT-PCR within nasopharyngeal swabs. Each case was evaluated with clinical data, laboratory tests and rectal swabs. The rectal swabs were obtained five days after nasopharyngeal positivity. The clinical data was recorded within two basic categories, including common symptoms or digestive symptoms. Detection of SARS-CoV-2 in rectal swabs was performed by RT-PCR method.

Results: Fifteen patients (30\%) had digestive symptoms. On the 5th day, 50 rectal swabs were studied with PCRRT. Only one of them was positive (2\%). The only patient who was positive for SARS-CoV-2 on rectal swab was a symptomatic threeand-a-half-year-old girl. The patient, who became asymptomatic in the follow-up, was retested with a nasopharyngeal swab one week later, the result was negative and she was discharged on the 10th day. The second rectal smear of the patient was negative.

Conclusion: We found very low rate (2\%) fecal viral shedding with rectal swab PCR among children who have been confirmed COVID-19 by nasopharyngeal swab PCR. We thought that this result was due to the mild clinical course of the patients who has been diagnosed with COVID-19 we followed up. However, fecal oral transmission might still matter in children.
\end{abstract}

Key Words: Children, COVID-19, Fecal shedding, Polymerase Chain Reaction

(1)

ISKENDER MAZMAN D DERECIS

DINC B

OZKAYA PARLAKAY A

OZKAYA PAR

YALCIN

KIRCA F

BERBEROGLU ATES B

DEMIR AM

HIZAL G

UNLUSOY AKSU A

HIZLIS
Conflict of Interest / Çıkar Çatışması: On behalf of all authors, the corresponding author states that there is no conflict of interest.

0000-0001-9244-5792 0000-0001-8689-3783 $0000-0001-8318-2556$ : $0000-0001-5601-2556$ : : $0000-0003-1691-764$ 0000-0003-0959-9091 0000-0003-4235-9428 0000-0002-9176-9100 0000-0003-0167-4990 :0000-0002-4550-0717 0000-0001-6732-493X

Ethics Committee Approval / Etik Kurul Onayl: The study was approved by the Ankara City Hospital, No. 1 Clinical Research Ethics Committee EK1-20-588). Made in May 2020 in accordance with the principles of the Declaration of Helsinki.

Contribution of the Authors / Yazarların katkısı: ISKENDER MAZMAN D: Constructing the hypothesis or idea of research and/or article, Planning methodology to reach the Conclusions, Taking responsibility in patient follow-up, collection of relevant biological materials, data management and eporting, execution of the experiments, Taking responsibility in logical interpretation and conclusion of the results, Taking responsibility in necessany

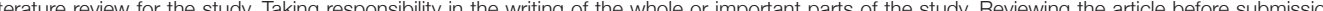
DERECIS: Organizing, supervising the course of progress and tak Taking responsibility in necessary literature review for the study, Taking responsibility in the writing of the whole or important parts of the study. Reviewing the article before submission scientifically besides spelling and grammar. DINC B: Taking responsibility in patient follow-up, collection of relevant biological materials, data management and reporting, execution of the experiments. OZKAYA PARLAKAY A: Taking responsibility in patient follow-up, collection of relevant biological materials, data management and reporting, execution of the experiments. YALCIN B: Taking responsibility in patient follow-up, collection of relevant biological materials, data management and reporting, execution of the experiments. KIRCA F: Taking responsibility in patient follow-up, collection of relevant biological materials, data management and reporting, execution of the experiments. BERBEROGLU B: Taking responsibility in patient follow-up, collection of relevant biolical materials, data management and reporting, execution of the experiments. DEMIR AM: G: Taking responsibility in patient follow-up, collection of relevant biological materials, data management and reporting, execution of the experiments. UNLUSOY AKSU A: Taking responsibility in logical interpretation and conclusion of the results, Taking responsibility in necessary literature review for the study, HIZLI S: Organizing, supervising the course of progress and taking the responsibility of the research/study. Reviewing the article before submission scientifically besides spelling and grammar.

How to cite / Atıf yazım șekli : Iskender Mazman D, Dereci S, Dinc B, Ozkaya Parlakay A, Yalcin B, Kirca F, et al. Assessment of Fecal Viral Shedding Among Children who Have COVID-19 by Polymerase Chain Reaction. Turkish J Pediatr Dis 2022;16:174-178.
Correspondence Address / Yazışma Adresi:

Selim DERECI

Ankara City Hospital,

Pediatric Gastroenterology Department, Ankara, Turkey

E-posta: dereciselim@hotmail.com
Received / Geliş tarihi : 02.03.2021 Accepted / Kabul tarihi : 04.05.2021 Online published Elektronik yayın tarihi

DOI: $10.12956 /$ tchd.889841 


\section{öz}

Amaç: Bu çalıșmada nazal sürüntüde real-time polimeraz zincir reaksiyonu (RT-PCR) ile COVID-19 tanısı doğrulanmıș çocuklarda , fekal viral bulaşmayı değerlendirmeyi amaçladık.

Gereç ve Yöntemler: Bölgemizdeki ilk salgın dalgası sırasında COVID-19 tanıı yatarak tedavi gören elli çocuğu çalıșmaya dahil ettik. Tüm hastaların nazofaringeal sürüntüleri RT-PCR ile iki kez pozitifti. Her vaka klinik veriler, laboratuvar testleri ve rektal sürüntü ile değerlendirildi. Rektal sürüntüler nazofarengeal pozitiflikten beș gün sonra alındı. Klinik veriler, genel semptomlar veya sindirim semptomları dahil olmak üzere iki temel kategoride kaydedildi. Rektal sürüntülerde SARS-CoV-2'nin tespiti, RNA'ya bağımlı RNA polimeraz genini hedefleyen RTPCR yöntemi ile gerçekleștirildi.

Bulgular: On beș hastada (\%30) sindirim sistemi ilișkili belirtiler görüldü. Hastalarda yoğun bakıma veya daha fazla tedaviye intiyaç duyulmadı. 5. günde PCR-RT ile 50 rektal sürüntü çalıșildı. Bunlardan sadece biri pozitifti (\%2). Rektal sürüntüde SARS-Cov 2 pozitif gelen tek hasta semptomatik ve üç buçuk yaşında bir kızdı. İzlemde asemptomatik hale gelen hasta bir hafta sonra nazofaringeal sürüntü ile tekrar test edildi, sonucu negatif geldi ve 10. gün taburcu edildi. Olgunun ikinci rektal sürüntüsü negatif olarak sonuçlandı.

Sonuç: Nazofaringeal sürüntü PCR ile COVID-19 doğrulanmış çocuklar arasında rektal sürüntü PCR ile dışkıda viral bulaşma oranının çok düşük olduğunu (\%2) bulduk. Bu sonucun, takip ettiğimiz COVID-19 tanısı alan hastaların hafif klinik seyrine bağlı olduğunu düşündük. Bununla birlikte, fekal oral yolla bulaşma çocuklarda hala önemini korumaktadır.

Anahtar Sözcükler: Çocuk ,COVID-19, Fekal Yayllım, Polimeraz zincir reaksiyonu

\section{INTRODUCTION}

The infectious disease due to SARS-CoV-2 ( Severe Acute Respiratory Disease Coronavirus-2) was defined as the novel Coronavirus Disease ( COVID-19), causing pandemic in 2020 (1). SARS CoV-2 is defined as a member in lineage B of betacoronavirus genus from Orthocoronavirinae subfamily in Coronaviridae family. It is enveloped, looks crown-like and has positive polarity RNA (2). The World Health Organization (WHO) declared a pandemic emergency on January 30, 2020 (3). The outbreak has been spread all over the world and resulted in a terrifying situation over 200 countries.

COVID-19 have been quickly spread via human-to-human and by travel between countries. The common symptoms are oftenly fever, fatigue, cough, headache, sore throat and rhinorrhea, respectively (4). Incubation period can differ from two to 10 days, however some editions have been stating that the duration may shift over two weeks in some cases (5). COVID-19 has a broad spectrum through mild upper respiratory infection to death. Clinical findings progress within six to 61 days after onset of early symptoms and fatality rate is about $2.2 \%$ overall (5). According to epidemiologic data from China, Italy and the USA pediatric patients have been ranked among $1.2-5 \%$ in all cases with COVID-19 (5). Mostly, asymptomatic courses are seen among children in COVID-19 $(2,6)$. Therefore, children may have high contagiousness and they are the perfect spreaders in the population.

Transmission of the disease occurs via droplet, aerosol or close contact with infected individuals (6). COVID-19 is typically characterized by respiratory manifestations, however gastrointestinal symptoms in some COVID-19 patients have also raisen concern about enteric involvement or fecal shedding $(7,8)$. The virus binds to angiotensin converting enzyme I(ACE 2), in which is expressed on intestinal epitels and this situation has been accounted to gastrointestinal involvement in COVID-19 (9). The disease spreads very quickly so that other transmission ways such as fecal route has also drawn attention except respiratory contagiousness. Meanwhile studies on the way of transmission of the virus continue, new mutations in the COVID-19 genetic structure have been just detected. How this situation will affect the epidemic is a matter of concern (10).

However, vaccination trials that have started all over the world seem promising for control of the epidemic. Vaccination is a very important way of fighting the epidemic, but the point is to prevent the transmission of the virus.

The most commonly used method in the follow-up of the pandemic has been the PCR test of respiratory tract swab in our country as well as all over the world.

In mild or severe cases, the first step is to perform the PCR in swabs for diagnosis. These PCR results are taken into account in the control of the pandemic, in the isolation and followup of individuals (11). PCR determines whether there is virus genetic material from the respiratory tract, so it may not give a clear idea about the prognosis of the disease.

However, for highly contagious outbreaks, it is more vital to identify and isolate individuals who carry the virus than to predict the prognosis of the disease in terms of public health. Fecal PCR is not routinely performed in cases with suspected spreaders in public. This part is a public health issue that needs to be studied.

In this study, we aimed to investigate viral shedding in rectal swabs among children who have COVID-19 by RT-PCR tests.

\section{MATERYAL and METHODS}

This study is achieved among fifty children ( $0-18$ years aged) who have COVID- 19 or referred with any COVID-19 associated symptoms or SARS-CoV -2 positivity in the nasopharyngeal swabs to Tertiary Referral Pandemic Hospital on June 1-30, 2020. We obtained their rectal swabs and assessed the viral RNA by RT-PCR, as well. The management, observation and treatment have been done according to the guideline of National Scientific Council (12). The study was conducted in accordance with the principles of the Helsinki Declaration, the 
ethics committee with issue EK1-20- 588 in May 2020. We took the own-signed informed consent forms from each patient and each their parents or legal guardians.

We collected the rectal swabs from patients who have SARSCoV-2 in their nasopharyngeal swabs on the fifth day. When the rectal swabs were obtained, we recorded the demographic data, any chronic diseases and symptoms; such as fever, cough, dyspnea or gastrointestinal symptoms (anorexia, abdominal discomfort, vomiting, diarrhea, stool solidity and stool frequency). We performed complete blood count, biochemical profiles, stool microscopic examination, stool cultures and chest graphy from each patient. Six patients who had more severe respiratory symptoms were also performed computed tomography(CT) of the thorax.

By end of the ten days of follow-up, nasopharyngeal swabs were obtained from each patient again and the RT-PCR tests were repeated with an interval of 24 hours. The patients who became negative twice were discharged with self isolation rules.

The exclusion criterias are non-having COVID-19 or to not accept to join the study. Any patients who have chronic diarrhea (Celiac disease, inflammatory bowel disease or etc..), infectious enteritis, immune deficiencies or using any medications for any reason except COVID-19 have not been enrolled in the study.

Detection of SARS-CoV-2 in rectal swab samples was performed by Real Time Reverse Transcriptase Polymerase Chain Reaction ( RT-PCR) method targeting RdRp ( RNA dependent RNA polymerase) gene. Sterile dacron swabs with flexible plastic shafts were used to collect samples from patients. After collection, swabs were placed into $2 \mathrm{~mL}$ of sterile Viral Transport Medium ( VTM; various manufacturers). Samples were transported and tested as soon as possible after collection. RNA extraction from swab samples were performed by using BioRobot EZ1 Advanced XL@ system (Qiagen, Hilden, Germany) using the EZ1 Virus Mini Kit(Qiagen, Hilden, Germany) according to the manufacturer's instructions. Real-time reverse transcription was performed by using Bio-speedy COVID-19 RT-qPCR. Detection Kit ( Bioeksen, Istanbul, Turkey). A $20 \mu \mathrm{l}$ reaction contained $5 \mu \mathrm{l}$ of RNA, $5 \mu$ l of oligo mix ( RdRp gene for SARS-CoV2 detection, Rnase P gene for internal control), $10 \mu$ of $2 x$ Primer Script mix containing Taq polymerase, each deoxy ribo triphosphates (dNTP), reverse transcriptase and ribonuclease inhibitor. Positive control for amplification control and no-template control to assess contamination were used. Thermal Cycling was performed at $45^{\circ} \mathrm{C}$ for 10 min for reverse transcription, followed by $95^{\circ} \mathrm{C}$ for 3 min and then 45 cycles of $95{ }^{\circ} \mathrm{C}$ for $5 \mathrm{~s}, 55^{\circ} \mathrm{C}$ for $35 \mathrm{~s}$ in Rotor-gene device (Qiagen, Hilden, Germany). Cycle threshold (Ct) values of less than 40 were defined as positive.

\section{Statistical Analysis}

SPSS ${ }^{\circledR}$, Version 21, software (Chicago, IL, USA) was used to perform statistical analysis. A descriptive analysis was used as mean and standard deviation for the characterization of the study population.

\section{RESULT}

The prospective cross-sectional study was carried out with 50 children, aged 0-18 years, with a definitive diagnosis of COVID-19 in Ankara City Hospital. The median age was 10.9 \pm 5.4 years, and ranged from 8 months to 17.9 years and $56 \%$ of group was male ( $44 \%$ female). Body weight and height were measured in each patient. All measurements were arranged in \pm 2 standard deviation (SD). No one in the groups has malnutrition. Two of the patients had been followed as diagnostic asthma and others have no comorbidity. The demographic data is seen Table I.

The most common symptoms were fever in 26 cases (52\%), cough in 20 cases (40\%), sore throat in 19 cases (38\%) and anorexia in 12 cases (24\%). Digestive symptoms were seen in 15 cases (30\%), who of them had anorexia in 12 cases (24\%) and diarrhoea in 11 cases (22\%). The other digestive symptoms were abdominal discomfort in 6 cases (12\%) and vomiting in 4 cases (8\%). One of the patients who have diarrhoea had watery diarrhoea 6-9 times per day for five days. The other ones had loose soiling just 1-3 times per day for 3 days as well. The abdominal discomfort has been associated with digestive symptoms in just three patients at all. The clinical data were demonstrated in Table II.

In this study, only one case of all patients who had upper respiratory positivity has been confirmed as positive by rectal swabs RT-PCR. The case was a three and a half years old girl. She had been cared for in a neonatal intensive care unit in her first two months because of respiratory distress syndrome and she has not got any other characteristic. She progressed well and become asymptomatic ten days after being diagnosed. After ten days follow up she was result as negative in nasopharyngeal swabs' RT-PCR and discharged. We called for her after discharge for getting a second rectal swab on the twentieth day of COVID-19, because that fecal shedding could extend over twenty days. Then the second rectal swab was analysed as negative.

The five patients had leukopenia, which their white blood cell count were less than $4 \times 10^{\%} / \mathrm{L}$ (normal range: $4.2-12 \times 10^{9} / \mathrm{L}$ ). The eight (16\%) of them had neutropenia, in which their absolute neutrophil were counted less than $1500 / \mathrm{mm}^{3}$ and 28 patients (56\%) had lymphopenia, in which the lymphocytes were counted less than $2000 / \mathrm{mm}^{3}$ as well. C- reactive protein (CRP) was tested as higher than normal range ( normal range: 0-0.005 gr/dl) in twelve children (24\%). D-dimer (normal range:

Table I: Demographic data of patients who had been confirmed by nasopharyngeal RT-PCR.

\begin{tabular}{l|c} 
& Study group $(\mathbf{n = 5 0}) \%$ \\
\hline Age( year) & $10.9 \pm 5.4$ \\
Gender & $28(56)$ \\
Male & $22(44)$ \\
\hline Female & \\
\hline
\end{tabular}

RT-PCR: real time polymerase chain reaction. 
Table II: The findings of patients who had been confirmed by nasopharyngeal RT-PCR

\begin{tabular}{l|c|c|}
\hline & $\mathbf{n = 5 0}$ & $\%$ \\
\hline Fever & 26 & 52 \\
\hline Cough & 20 & 40 \\
\hline Sore Throat & 19 & 38 \\
\hline Myalgia & 4 & 8 \\
\hline Anosmia/Ageusia & 3 & 6 \\
\hline Headache & 3 & 6 \\
\hline Losing weight & 2 & 4 \\
\hline Dyspnea & 1 & 2 \\
\hline Digestive symptoms & 15 & 30 \\
Anorexia & 12 & 24 \\
\hline Diarrhea & 11 & 22 \\
\hline Abdominal Discomfort & 6 & 12 \\
\hline Vomiting & 4 & 8 \\
\hline RT-PCR
\end{tabular}

RT-PCR: real time polymerase chain reaction

Table III: The laboratory results of patients.

\begin{tabular}{|c|c|c|}
\hline & $n=1$ & $\%$ \\
\hline Nasopharyngeal swabs positivity & 50 & 100 \\
\hline Rectal swabs positivity & 1 & 2 \\
\hline White blood cell< 4 x10\%/L & 5 & 10 \\
\hline $\begin{array}{l}\text { Absolute Neutrophils }<1500 / \mathrm{mm} \\
<1500<1500 / \mathrm{mm}^{3}\end{array}$ & 8 & 16 \\
\hline Lymphocytes $<2000 / \mathrm{mm}^{3}$ & 28 & 56 \\
\hline C-reactive protein $>0.005 \mathrm{gr} / \mathrm{L}$ & 12 & 24 \\
\hline D-Dimer >0.55 mgr/L & 9 & 18 \\
\hline Procalcitonine $>0.16 \mathrm{mcgr} / \mathrm{L}$ & 1 & 2 \\
\hline
\end{tabular}

WBC: white blodd cell, CRP: C-reactive protein

$<0.55 \mathrm{mg} / \mathrm{dll}$ ) was elevated in nine patients (18\%) as well and procalcitonine was high in just one patient. The blood chemistry and metabolic panels were measured as unremarkable among all patients. The stool analysis was seen as normal in all patients. Twenty patients (40\%) had been diagnosed as atypical pneumonia by chest graphy, in which had interstitial infiltration or ground glass densities via $x$-ray. They had no severe respiratory symptoms (tachypnea, retraction or hipoxemia). The six patients who had much more cough or been lasting over three days with fever had been also evaluated via torax CT. Two patients who were diagnosed pneumonia by tomography and they have been treated according to guidelines. Laboratory data were demonstrated in Table III.

\section{DISCUSSION}

Since COVID-19 outbreak terrifying the world, respiratory symptoms and transmission via droplet have been known very well and precautions have been settled properly as much as it can. On the other hand gastrointestinal shedding, digestive symptoms, fecal fomites even that stool PCR are lesser known at all in childhood $(13,14)$.

Cheung et al. (8) have reported a multi center study by gathering from six different countries, in which 4123 symptomatic and confirmed nasopharyngeal PCR cases (including adult or pediatric patients and pregnant women) were investigated. In that report, the leading digestive symptoms were common such as anorexia (26.8\%), diarrhoea (12.5\%), nausea/vomiting (10.2\%) and abdominal discomfort (9.6\%). According to the same study, fecal RNA was found as $15.3 \%$ in either who had digestive symptoms or not. Digestive symptoms have been found similar to the other studies, including anorexia (24\%), abdominal discomfort (12\%) and vomiting (8\%), except diarrhoea (22\%) which is more common in our study.

In the 2020, early stage of outbreak, Wang et al. (15) had reported the frequency of diarrhea to be $3 \%$ in infectious disease caused by the SARS-CoV-2 virus. In the same publication, diarrhea frequency rates in old coronavirus infectious diseases are respectively; It is 26\% in MERS-CoV and $20-25 \%$ in SARSCoV. In our study we found that diarrhea is more common in COVID-19 in childhood but all cases had good clinical spectrum and discharged with recovery.

Zhang et al. (16) have found viral RNA in stool as 6.5\% among adults who have COVID-19. They also reported that respiratory shedding can either exceed ten days or fecal shedding can last over 22 days. As regards another paper in 2004, there had been reported that SARS-CoV was confirmed in stool and respiratory samples on the fifth day of the disease (17). However, Xing et al. (18) reported that SARS CoV-2 is still able to found in stool samples up to fourth week after fever has been recovered. Zimmerman et al. (19) have been reported that viruses can be either isolated from nasopharyngeal way for 22 days, or isolated from fecal way over 30 days. Wang et al. (20) reported that fecal viral positivity that $20(28.99 \%)$ of 69 patients had positive fecal viral tests in their patients. They also stated that they observed more positive clinics in the fecal positivity group and much longer positivity than oropharyngeal positive ones. However the mentioned trials also reported that their patients had more serious clinical spectrums compared to our patients. Previous studies showed very different positivity rates of SARS-CoV-2 RNA in fecal swabs. The different rates of positive RNA tests may be due to the small size of samples, mild to severe clinical spectrums, discontinuous detection and different timing of testing.

According to a meta-analysis confirms that SARS-CoV-2 RNA is present in feces of a high proportion of children with COVID-19 and that fecal viral RNA shedding lasts longer even after the respiratory tract have become negative with RT-PCR tests (21).

In our study, we found fecal shedding is much less $(2 \%)$ by comparison with literature. Only a single case was found as positive in a rectal swab sample. Second rectal swab getting from the case was found as negative on the twentieth day after 
discharge. We have mostly seen COVID-19 in a mild clinical spectrum in children. The pediatric cases do not generally need treatment and there is also no need to intervene. Limited evidence exists on whether SARS-CoV-2 RNA shedding from stools is infectious and whether fecal viral shedding plays a role in the dissemination of infection. There may be a limitation here in this study because of mild clinical spectrum in our study group. In essence, we were mainly looking for a relationship between stool sample positivity, mild clinical spectrum and transmissibility. As is known, much more serious clinical findings already mean much more contagiousness. Herein reel point is that which should be answered by scientists how much are super spreaders contagious in the public. There needs to large surveillance trials for understanding that question.

In conclusion, we found very low-rate viral shedding in stool (2\%) with rectal swab PCR among children who have been confirmed COVID-19 by nasopharyngeal swab PCR. We thought that this result was due to the mild clinical course of the pediatric patients who had been diagnosed with COVID-19 we followed up. However, one should be cautious about fecal- oral transmission in COVID-19. Further studies with larger patient groups are needed.

\section{What is already known on this topic}

- Children are superspreaders during COVID-19 outbreak.

- Children have mostly mild clinical spectrum or asymptomatic.

- The transmission routes of Sars CoV-2 virus other than the respiratory tract are still not well known.

\section{What this paper adds:}

- Children may not spread Sars-CoV-2 virus in the stool as much as the respiratory tract.

- Excretion with feces may depend on the severity of the disease?

- Broad epidemiological studies are needed to understand the correlation between this transmission and the clinical picture.

- There is a need a validated test for fecal viral shedding other than the current swab PCR test.

\section{REFERENCES}

1. Zhu N, Zhang D, Wang W, Li X, Yang B, Song J, et al. A Novel Coronavirus from Patients with Pneumonia in China, 2019. N Engl J Med 2020; 382:727-33.

2. Tezer H, Bedir Demirdag T. Novel coronavirus disease (COVID-19) in children. Review Article. Turk J Med Sci 2020;50: 592-603.

3. Available from: URL: https://www.who.int/csr/don/12-january2020-novel-coronavirus-china/en/

4. Di Gennaro F, Pizzol D, Marotta C, Antunes M, Racalbuto V, Veronese N, et al. Coronavirus Diseases (COVID-19) Current Status and Future Perspectives: A Narrative Review. Int J Environ Res Public Health 2020;17:2690.
5. Ludvigsson JF. Systematic review of COVID-19 in children shows milder cases and a better prognosis than adults. Acta Paediatrica 2020;109:1088-95.

6. Ren SY, Wang BW, Hao YG, Zang HR, Wang ZC, Chen YL, Gao RD. Stability and infectivity of coronaviruses in inanimate environments. World J Clin Cases 2020; 8:1391-9.

7. Yeo C, Kaushal S, and Yeo D. Enteric involvement of coronaviruses: is fecal-oral transmission of SARS-CoV-2 possible? Lancet Gastroenterol Hepatol 2020; 4: 335-7.

8. Cheung KS, Hung I FN, Chan P PY, Lung KC, Tso E, Liu R, et al. Gastrointestinal Manifestations of SARS-CoV-2 Infection and Virus Load in Fecal Samples from the Hong Kong Cohort and Systematic Review and Meta-analysis. Gastroenterology 2020;159:81-95.

9. Liang W, Z Feng, Rao S, Xiao C, Xue X, Lin Z, et al. Diarrhoea may be underestimated: a missing link in 2019 novel coronavirus. Gut 2020;69:1141-3.

10. Hasan MR, Sundararaju S, Manickam C, Mirza F, Al-Hail H, Lorenz $\mathrm{S}$, et al. A novel point mutation in the $\mathrm{N}$ gene of SARS-CoV-2 may affect the detection of the virus by RT-qPCR. J Clin Microbiol 2021;59:e03278-20.

11. Xu CLH, Raval M, Schnall, JA, Kwong, JC, Holmes NE. Duration of Respiratory and Gastrointestinal Viral Shedding in Children With SARS-CoV-2: A Systematic Review and Synthesis of Data. Pediatr Infect Dis J 2020;39:e249-56.

12. Available from: URL:https://COVID19bilgi.saglik.gov.tr/depo/ rehberler/COVID19_Rehberi.pdf

13. Zhang JC, Wang SB, Xue YD. Fecal specimen diagnosis 2019 novel coronavirus-infected pneumonia. J Med Virol 2020;92:6802.

14. Xu Y, Li X, Zhu B, Liang H, Fang C, Gong Y, et al. Characteristics of pediatric SARS-CoV-2 infection and potential evidence for persistent fecal viral shedding. Nat Med 2020;26: 502-5.

15. Wang C, Horby PW, Hayden FG, Gao GF. A novel coronavirus outbreak of global health concern. Lancet 2020; 395:470-3.

16. Zhang N, Gong Y, Meng, Shi Y, Wang J, Mao P, et al. Comparative study on virus shedding patterns in nasopharyngeal and fecal specimens of COVID-19 patients. Sci China Life Sci 2020;5:1-3. doi: 10.1007/s11427-020-1783-9.

17. Chan KH, Poon LLM, Cheng VCC, Guan Y, Hung IFN, Kong J et al. Detection of SARS Coronavirus in Patients with Suspected SARS. Emerg Infect Dis $2004 ; 2: 294-9$.

18. Xing YH, Ni W, Wu Q, Li WJ, Li GJ, Wang WD, et al. Prolonged viral shedding in feces of pediatric patients with coronavirus disease 2019. J Microbiol Immunol Infect 2020;53:473-80.

19. Zimmermann P, Curtis N. COVID-19 in Children, Pregnancy and Neonates A Review of Epidemiologic and Clinical Features. Pediatr Infect Dis 2020;39:469-77.

20. Wang X, Zheng J, Guo L, Yao H, Wang L, Xia XD, et al. Fecal viral shedding in COVID19 patients: Clinical significance, viral load dynamics and survival analysis. Virus Res 2020; 289:198147

21. Santos VS, Gurgel RQ, Cuevas LE, Martins-Filho PR. Prolonged fecal shedding of SARSCoV-2 in pediatric patients. A quantitative evidence synthesis. Meta-Analysis J Pediatr Gastroenterol Nutr 2020;71:150-2. 